\title{
TRADISI HANTA UA PUA SEBAGAI UPAYA PELESTARIAN BUDAYA RELIGI DI BIMA
}

\author{
Nurrofika $\left({ }^{1}\right.$ *), Mukhamad Murdiono $\left({ }^{2}\right)$ \\ ${ }^{12}$ Department of Civic Education, Graduate School of Universitas Negeri Yogyakarta, Indonesia.
}

\section{ARTICLE INFORMATION}

$\begin{array}{ll}\text { Submitted } & : 23^{\text {rd }} \text { August, } 2019 \\ \text { Review } & : 29^{\text {th }} \text { August, } 2019 \\ \text { Accepted } & : 03^{\text {rd }} \text { May, 2020 } \\ \text { Published } & : 1^{\text {st }} \text { June } 2020 \\ \text { Available Online } & : \text { June } 2020\end{array}$

\section{KEYWORDS}

Local wisdom; Tradition; Culture; Values; Bima

\section{CORRESPONDENCE}

E-mail:nurrofikaa@gmail.com

\section{A B S T R A C T}

\begin{abstract}
Bima has many traditions and local wisdom that should continuously preserve, one of which is the traditional ceremonies of Hanta Ua Pua. This tradition is one of the Bima conventional ceremonies in the context of enlivening the birthday of the great prophet Muhammad. The purpose of writing this article is to find out the implementation and values contained in the Hanta Ua Pua traditional ceremonial religious tradition as an effort to preserve Islamic culture in Bima. This article prepares using the method of library research, which is a method of data collection that is carriers out by utilizing the sources and materials of the library. The results and conclusions obtained are the traditional ceremonies of the Hanta Ua Pua ceremony, which are a memorial and a tribute event to the teachings of Islam and scholars. Done since the Sultanate of Bima. The values in this ceremony divide into three, namely social values, spiritual values, and educational values. The Hanta Ua Pua traditional ceremonies are evidence of the entrance and development of Islamic culture in Bima, which is expected to grow and develop the character of the Bima people who can continue to hold fast to Islamic teachings. However, along with the times, the ceremony began to fade in Bima.
\end{abstract}

\section{A. PENDAhUluan}

$\mathrm{B}$ udaya merupakan sebuah sistem yang mencakup banyak hal setidaknya seperti bahasa, musik, benda, kepercayaan dan juga aktivitas masyarakat yang didalamnya mengandung makna kebersamaan serta saling memiliki hubungan antara lainnya (Yunus: 2014). Budaya itu sendiri akan selalu melekat pada suatu masyarakat sehingga akan selalu diterapkan dari generasi ke generasi. Oleh karena itu, setiap kelompok masyarakat pasti memiliki budayanya masing masing. Budaya tersebut dipegang teguh oleh tiap-tiap individu dari setiap kelompok masyarakat. Di indonesia sendiri, tiap-tiap daerah memiliki latar belakang sosio-budaya yang beraneka ragam dan berbeda dengan yang lainnya, yang salah satunya adalah budaya yang dimiliki daerah Bima.
Daerah Bima ini sendiri terletak di pulau Sumbawa di bagian ujung timur provinsi Nusa Tenggara Barat. Tanah Bima atau sering disebut oleh masyarakatnya dengan Dana Mbojo telah mengalami perjalanan yang panjang dan sudah mengakar jauh ke dalam sejarah nusantara. Pada tahun 1950, daerah Bima yang juga bisa disebut dengan Sunda Kecil ini berbatasan dengan Samudra Indonesia di bagian selatan, Laut Flores di bagian utara, kabupaten Dompu dan Sumbawa di bagian barat serta Selat Sape di bagian timur (Ismail: 2008).

Kemudian, berdasarkan sensus penduduk pada tahun 1982 yang dilakukan oleh Kantor Statistik Daerah Kabupaten Tingkat II, Masyarakat Bima sendiri terdiri dari dou mbojo (orang Bima) yang merupakan pembauran dari orang Bima, orang Makassar dan orang Bugis, 
kemudian ada dou donggo (orang Donggo) yang merupakan orang asli Bima dan yang terakhir kaum pendatang di mana yang paling besar pengaruhnya ialah orang Melayu dan orang Arab (Ismail: 2004). Hal ini tentu saja mempengaruhi pertumbuhan dan perkembangan budaya Bima yang beragam. Sebagaimana diketahui, tradisi dan kebudayaan dapat dipengaruhi oleh letak geografis, keadaan, struktur dan iklim suatu wilayah yang keberadaannya memberikan pengaruh yang besar terhadap kehidupan masyarakatnya.

Di samping itu, sebagai makhluk pluralis yang memiliki rasa, cipta dan karsa, manusia tentu ingin menciptakan kehidupan yang dapat menandai eksistensinya. Hal ini tentu saja harus ditopang dengan kemampuan berpikir, kemampuan merasa dan kemampuan berbuat yang dikembangkan dengan cara menilai, menafsir dan memprediksi keadaan alam dan lingkungan sepanjang waktu sehingga terciptanya suatu kebudayaan.

Di indonesia pada umumnya masih banyak orang yang sering menyamakan arti dari kebudayaan dan peradaban. Namun, dalam perkembangan ilmu antropologi, kedua istilah ini merupakan dua hal yang memiliki perbedaan arti. Peradaban diartikan sebagai manisfestasi dari kemajuan mekanis, teknologi, dan ekonomi, sementara kebudayaan adalah ungkapan semangat yang mendalam dari/pada suatu kelompok masyarakat yang direfleksikan dalam seni, sastra, religi, nilai dan moral (Panggabean, 2015: 16).

Wujud kebudayaan ini pada hakekatnya dapat di bagi menjadi dua, yaitu yang bersifat fisik (tangible) dan bersifat non-fisik (intangible). Salah satu wujud kebudayaan non-fisik merupakan sistem kepercayaan yang penghormatan dan penyembahannya dilakukan dengan cara upacara, doa, sajian atau korban yang kesemuanya bisa disebut kearifan lokal suatu daerah (Saputra \& Nurbaiti, 2010:2-3). Sementara kearifan lokal sendiri lahir dari pemikiran dan nilai-nilai yang di yakini oleh masyarakat suatu daerah terhadap lingkungannya yang memiliki kandungan nilai-nilai, norma dan sistem kepercayaan serta ide-ide (Rapanna, 2016: 11).

Setiap kelompok masyarakat di suatu daerah tentu saja memiliki kearifan lokal sendiri yang tetap berusaha dan terus mereka tumbuhkembangkan sebagai tanggapan aktif terhadap lingkungannya. Begitu juga dengan daerah Bima. Adanya berbagai ritual dan tradisi yang terus dilakukan merupakan bukti yang memperkuat keberadaan nilai-nilai dan ajaran agama dan kepercayaan di tengah masyarakatnya serta menjadi produk budaya masa lalu yang patut secara terus-menerus dan berkelanjutan di- jadikan sebagai pegangan hidup dan menjadi identitas sendiri dari daerah Bima.

Pegangan hidup dan identitas ini dapat dibentuk oleh ras, etnik, kasta, latar belakang yang merupakan pengusung dari kebudayaan (Mardotillah, 2016). Tidak berlebihan jika tradisi Upacara adat Hanta ua pua dapat disebut sebagai salah satu ciri khas identitas budaya daerah Bima. Bima sendiri memiliki begitu banyak tradisi dan kebudayaan yang sudah sepatutnya dilestarikan dan dijaga keberadaannya. Salah satu dari banyaknya kearifan lokal dari budaya di daerah Bima yang masih dan terus berusaha dilestarikan oleh masyarakatnya adalah tradisi upacara adat Hanta Ua Pua yang dibawa dan diperkenalkan oleh mubaliq Islam pada masa kepemimpinan Sultan Abdul Khair Sirajuddin pada tahun 1640-1682.Tradisi upacara adat Hanta Ua Pua merupakan tradisi upacara adat Bima dalam rangka memeriahkan Maulid Nabi Besar Muhammad SAW yang dilakukan sajuma'a (sejumat atau sepekan) pada wura molu (bulan maulud atau Rabiul Awal) (Muhammad, 2010:12). Tradisi upacara adat ini memiliki banyak nilai dan pembelajaran sehingga dapat menjadi suatu wadah dalam menyebarkan nilai-nilai.

Hal ini dapat kita dilihat dalam penelitian sebelumnya yang telah dilakukan oleh (Asbah, 2017:17-18) yang menyatakan bahwa tradisi upacara adat ini juga menjadi salah satu wahana masyarakat Bima dalam menyebarkan syiar Islam. Tradisi upacara adat Hanta Ua Pua menjadi salah satu media dakwah dalam hal meningkatkan keimanan dan ketaqwaan masyarakat Bima terhadap Al Quran dan hadist.

Kemudian dalam penelitian (Zuriatin \& Nurhasanah, 2018:137), tradisi upacara adat Hanta Ua Pua ini juga digambarkan sebagai simbol kesepekatan sultan, ulama dan seluruh rakyat Bima untuk berkomitmen dan mencintai kitab suci Al-Qur'an dan menjadikannya sebagai pedoman hidup. Selain itu tradisi ini juga menjadi salah satu bukti perpaduan antara nilai-nilai Islam dengan adat istiadat serta kepercayaan yang berkembang di masyarakat Bima. Selain itu, dalam penelitian yang tulis oleh (Jumiati: 2017) menyatakan bahwa upacara adat Hanta Ua Pua ini juga menjadi salah satu wadah dalam menyalurkan bakat serta memotivasi para seniman dan budayawan dalam hal menciptakan karya seni yang bermutu yang layak dan dapat dipertunjukan dalam pelaksanaan upacara adat ini. Selain itu dengan adanya tradisi upacara adat Hanta Ua Pua ini dapat dijadikan tolak ukur serta apresiasi masyarakat terhadap seberapa pentingnya keberadaan suatu budaya.

Hal tersebut diperkuat oleh tulisan (Mahmud: 2008) yang menyatakan bahwa pada hakekatnya tradisi upacara adat Hanta Ua Pua merupakan 
media dakwah guna meningkatkan keimanan dan ketaqwaan masyarakat Bima agar menjadikan Al-Quran dan hadist sebagai satusatunya pedoman hidup mereka dalam tatanan kehidupan bermasyarakat namun tetap sesuai dengan nggusu waru dan adat istiadat Bima. Dalam Nggusu waru sendiri berbunyi "dou maja labo dahu dei ndai Ruma Allahu Ta'ala" yang artinya orang yang merasa malu dan takut kepada Allah SWT. Hal ini merupakan perintah kepada seluruh lapisan masyarakat. Masyarakat harus memiliki rasa malu dan takut kepada Allah SWT, manusia lainnya, lingkungan dan pada dirinya sendiri untuk melakukan hal yang tidak sesuai dengan ajaran agama islam (Ismail, 2001:46-47). Namun, pada kenyataannya tradisi upacara adat Hanta Ua Pua ini juga sempat terhenti pasca wafatnya sultan ke-14,yaitu Sultan Muhammad Salahuddin yang terkenal dengan gelarnya Ma Kakidi Agama (yang menegakkan agama) pada tahun 1951 yang bersamaan dengan berakhirnya masa kesultanan Bima. Pemberhentian tradisi upacara adat hanta ua pua ini tentu saja memberikan dampak pada masyarakat Bima yang dimana mengalami kehilangan suatu momentum serta tuntunan hidup yang berpengaruh sangat penting terhadap penanaman nilai-nilai keagamaan mereka.

Dampak dari pemberhentian tradisi upacara adat Hanta Ua Pua ini menyebabkan masyarakat Bima kehilangan momentum kebersamaan sehingga mereka berusaha mengadakannya kembali pada tahun 1952 namun dihalangi oleh sekelompok ulama sendiri dengan menggunakan dalih bahwa tradisi upacara adat Hanta Ua Pua tersebut berjiwa feodal. Namun, pada tahun 2002 tradisi upacara adat ini mulai digelar kembali setelah Majelis Adat Dana Mbojo mengusulkan kepada pemerintah kota dan pemerintah kabupaten Bima. Sehingga, dapat di jadikan suatu pembelajaran bahwa dengan adanya peristiwa pemberhentian pelaksanaan tradisi upacara adat Hanta Ua Pua yang pernah dilakukan sebelumnya, tidak menutup kemungkinan akan terjadi pemberhentian kembali pelaksanaannya mengingat keberadaan dan pelaksanaan tradisi upacara adat Hanta Ua Pua ini makin hari makin dinilai sebagai acara perayaan biasa dengan ditandai oleh semakin kurangnya orang yang datang memeriahkan.

Disamping itu, tradisi upacara adat Hanta Ua Pua ini sering dimaknai hanya sebagai simbol serta media dakwah dalam menyebarkan syiar agama Islam jaman dulu sehingga masih banyak masyarakat Bima pada zaman sekarang terutama generasi muda yang belum benarbenar mengetahui tujuan, manfaat, nilai-nilai serta pesan-pesan moral yang terkandung dalam tradisi upacara adat ini. Di sisi lain, adanya pembangunan dan majunya ilmu pengetahuan dan teknologi juga tentunya mempengaruhi tumbuh dan kembangnya suatu budaya di suatu daerah paling tidak dengan adanya pergeseran nilai-nilai dalam kehidupan bermasyarakat. Hal inipun tentu saja juga terjadi di daerah Bima. Dari hal tersebut, pelestarian budaya upacara adat Hanta Ua Pua ini menjadi salah satu hal yang penting dilakukan. Pelestarian budaya ini juga seiring dengan himbauan UNESCO yang telah mengingatkan kepada bangsa-bangsa di dunia bahwa betapa pentingnya jati diri bangsa atau masyarakat di era globalisasi ini (Sedyawati: 1997).

Berdasarkan penjelasan di atas, untuk menjaga dan mepertahankan budaya tradisional seperti budaya Hanta Ua Pua ini diperlukan perhatian khusus untuk tetap menjaga dan melestarikannya mengingat keberadaan suatu budaya tidak bersifat statis melainkan dinamis sehingga akan terus selalu mengalami perubahan seiring berjalannya waktu. Sementara itu, budaya religi yang dimaksudkan dalam penelitian ini adalah budaya yang muncul dari pengaruh masuk dan berkembangnya suatu kepercayaan yaitu agama islam di daerah Bima yang terefleksikan dalam suatu tradisi keagamaan yaitu upacara adat Hanta Ua Pua yang kemudian menjadi salah satu ciri dan identitas diri yang tidak dapat dipisahkan dari kehidupan masyarakat Bima. Sehingga, sebagai salah satu ciri dan identitas diri yang menggambarkan budaya religi di daerah Bima serta kenapa tradisi upacara adat Hanta Ua Pua ini penting dan harus terus dilaksanakan dan dilestarikan, menjadi hal yang sangat penting untuk mengetahui terlebih dahulu tujuan dan manfaat dari pelaksanaan tradisi upacara adat ini serta nilai-nilai dan pesan-pesan moral apa saja yang terkandung didalamnya.

Untuk menjawab pertanyaan-pertanyaan tersebut, tulisan ini bertujuan untuk mendeskripsikan berkembangnya ajaran Islam di tanah Bima dengan cara menggali nilai-nilai serta pesanpesan moral yang terdapat dalam tradisi upacara adat hanta ua pua ini. Penulis juga berharap tradisi seperti ini dapat terus dipertahankan dan dilestarikan karena merupakan aset budaya yang menjadi salah satu identitas bangsa. Selain itu, tujuan lainnya adalah agar tradisi upacara adat hanta ua pua ini dapat menjadi salah satu model alternatif sekaligus daya tarik bagi wisatawan lokal maupun asing untuk berkunjung dan belajar tentang daerah Bima sendiri.

\section{B. METODE PENELITIAN}

$\mathrm{P}$ enelitian ini menggunakan jenis penelitian library research (penelitian kepustakaan) yang dilakukan dengan menggunakan literatur (kepustakaan) baik berupa buku, 
catatan, maupun laporan hasil penelitian dari penelitian terdahulu. Sumber data di dapat dari dokumen atau studi dokumen. Studi dokumen yaitu mencari data mengenai hal-hal atau variabel yang berupa catatan atau transkrip, buku, surat kabar, majalah, prasasti, notulen rapat, lengger, agenda dan sebagainya (Arikunto: 2010).

Teknik pengumpulan data dalam penelitian ini dilakukan dengan cara mengkaji dan menelaah berbagai sumber seperti buku, majalah, jurnal hasil penelitian, artikel, makalah, surat kabar, web (internet), atau informasi lain yang berhubungan dengan judul dan tujuan dari penelitian. Setelah data-data tersebut terkumpul selanjutnya dilakukan analisis data. Analisis data dalam penelitian ini adalah menganalisis dan mensintesiskan dokumen tersebut untuk dikaji sehingga menjadi gagasan baru dalam menunjang hasil penelitian.

\section{HASIL DAN PEMBAHASAN}

\section{A. Kedatangan Islam di Bima}

B ima merupakan salah satu daerah yang bisa dibilang terlambat mengenal ajaran Islam. Masuk dan tersebarnya ajaran Islam di tanah bima bisa dijelaskan melalui beberapa tahap yaitu di antaranya: tahap pertama, Islam masuk ke daerah Bima dibawa oleh mubaliq dan pedagang dari Demak dan Gresik. Islam dibawa dengan damai yaitu dengan cara para mubaliq langsung menghadap raja dan mengajaknya untuk memeluk ajaran islam. Kemudian tahap kedua, Islam masuk ke Bima melalui Ternate dan Sulawesi Selatan. Misi Islam yang dibawa tentu saja penuh dengan kedamaian dengan menggunakan jalur perdagangan dan hubungan kekeluargaan (Tajib, 1995:110).

Sebagaimana yang sudah dijelaskan di atas, Islam datang ke daerah Bima dari dua arah yaitu dari jawa dan dari Sulawesi Selatan. Namun, tidak ada yang benar-benar bisa memastikan mubaliq dari daerah mana yang pertama kali datang dan menyebarkan syiar Islam tersebut. Sementara jikalau membahas tentang awal masuknya Islam ke daerah Bima dan sumber datangnya, maka bisa di pastikan bahwa Islam masuk ke Bima bersumber dari Makassar dan lewat jalur Utara (Rachman, 2009:85), sehingga dapat ditarik kesimpulan bahwa kedatangan islam di daerah Bima dibawa oleh para mubaliq dan pedagang dan dilakukan secara damai.

Proses islamisasi di Bima juga dilakukan dengan cara damai oleh para ulama ataum mubaliq ditengah-tengah masyarakat Bima yang sudah dipengaruhi oleh kepercayaan lama yang sudah menjadi bagian dari kehidupan mereka.
Hal ini juga berlaku terhadap berbagai budaya yang telah mendapatkan pengaruh kepercayaan lama, namun hal itu tidak langsung dibubarkan oleh para ulama atau mubaliq akan tetapi mereka berusaha untuk memasukkan kedalamnya unsurunsur dan nilai-nilai yang berasaskan ajaranajaran agama Islam seperti halnya dengan tradisi upacara adat hanta ua pua yang pelaksanaannya berlandaskan kecintaan terhadap Allah SWT dan baginda rasul Muhammad SAW.

\section{B. Tradisi Upacara Adat Hanta Ua Pua 1. Pelaksanaan Upacara Adat Hanta Ua Pua}

Menurut Ranjabar (2006) pelestarian budaya lokal merupakan salah satu cara masyarakat dalam mempertahankan nilai seni budaya dan nilai tradisional dengan menyesuaikannya dengan situasi yang dinamis dimana akan terus berubah-ubah dan berkembang. Adanya pelestarian budaya ini dibutuhkan dalam rangka menjaga, mempertahankan dan melindungi keberadaan budaya lokal atau tradisional. Pelestarian tradisi upacara adat Hanta Ua Pua ini menjadi sangat penting dilakukan karena menyadari derasnya arus perkembangan zaman dan teknologi yang bisa menyebabkan masyarakat Bima meninggalkan dan berhenti melaksanakannya.

Disamping itu juga, sudah seharusnya semua kalangan di Indonesia secara umum, dan di daerah Bima secara khusus untuk membangun dan mengembangkan kesadaran terhadap nilai budaya yang dalam hal ini juga bersamaan dengan mempertahankan jati diri bangsa dan kearifan lokal agar tetap bisa berdiri tegak ditengah derasnya arus globalisasi dan modernisasi ini. Oleh karenanya, tradisi upacara adat Hanta Ua Pua dan nilai-nilai yang terkandung didalamnya harus tetap terus dilestarikan dan tatap dijaga keberadaannya karena menjadi salah satu perwujudan identitas masyarakat Bima yang dekat dengan ajaran agama Islam yang diselaraskan dengan adat istiadat sara dana mbojo (sesuai dengan cara dan hidup masyarakat Bima).

Tradisi upacara adat Hanta Ua Pua ini diperkenalkan pertama kali pada masa pemerintahan sultan Abdul Khair Sirajuddin pada tahun 1640-1682. Pada masa itu, perkembangan agama Islam mengalami pasang surut karena keadaan dimana agama Islam merupakan agama yang baru berusia belasan tahun sebagai agama kerajaan serta dengan adanya kepribadian sultan yang kurang perhatian dan peduli terhadap pentingnya ajaran agama Islam dan lebih mencintai seni dan budaya. Hal ini tentu saja tidak mengagetkan, mengingat pada awal sebelum masuknya agama Islam di daerah Bima, 
masyarakat Bima sendiri masih percaya bahwa ada kekuatan yang mereka sebut sebagai "Parafu" (Fitriana, 2019).

Hal ini tentu menyebabkan para ulama harus merencanakan dan merancang berbagai kegiatan dakwah melalui pertunjukan dan atraksi kesenian yang islami yang tujuannya dapat memikat hati Sultan. Di samping tujuannya menarik perhatian Sultan terhadap ajaran Islam, tradisi upacara hanta ua pua ini juga diadakan bersamaan dalam rangka memperingati hari Maulid nabi besar Muhammad SAW (Tajib, 1995).

Ua Pua sendiri merupakan satu kesatuan tangkai bunga dolu (telor) yang berjumlah 99 biji yang merupakan manifestasi dari asmaul husna (nama-nama Allah) yang sudah dihias dengan berbagai warna yang kemudian ditancapkan pada suatu wadah bersama sirih dan pinang. Kemudian pada bagian tengah dari wadah tersebut diletakkan sebuah kitab suci Alquran (Muhammad, 2010). Ua Pua ini kemudian ditempatkan pada sebuah Uma Lige (rumah Lige) yang berbentuk segi empat berukuran $4 \times 4 \mathrm{~m}$ yang dibuat menyerupai miniatur masjid sebagai simbol kebesaran Allah SWT. Uma Lige (rumah Lige) tersebut diusung oleh 44 orang pria sebagai simbol dari keberadaan 44 keahlian dan keterampilan yang dimiliki pemerintahan kesultanan Bima. Rombongan ini melakukan perjalanan dari Kampung Melayu menuju Asi Mbojo (Istana Bima) yang kedatangannya disambut oleh Sultan dengan pesan yang harus dikerjakan yaitu memegang teguh ajaran agama Islam.

Pelaksanaan tradisi upacara adat Hanta $\mathrm{Ua}$ Pua ini di mulai dari kegiatan atraksi seni tradisional serta pengajian bersama. Semua rakyat Bima yang datang berkumpul di lapangan Sera Suba dari pukul 06.00 pagi. Kemudian tokoh masyarakat Bima baik tokoh adat, agama maupun pejabat kesultanan bersama para penari lenggo mbojo di utus oleh Sultan untuk menjemput penghulu melayu di kampung melayu.

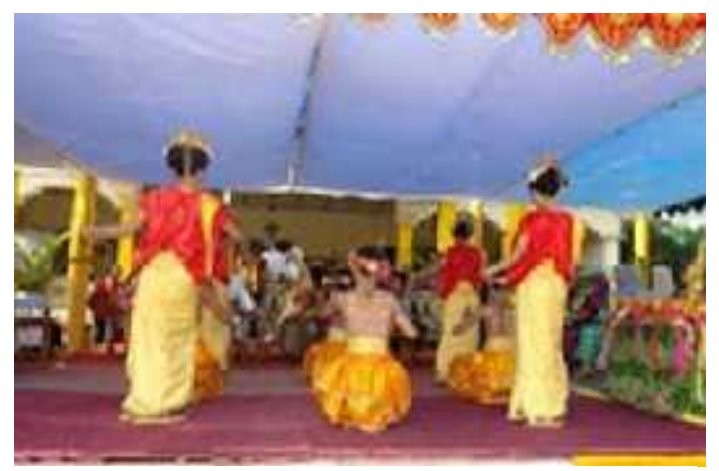

Gambar 1: Tari Lenggo
Kemudian penghulu melayu yang telah di jemput oleh para utusan sultan ini mulai melakukan perjalanan dari kampung Melayu menuju Asi Bima (istana Bima). bersamaan dengan rombongan penghulu melayu berjalan menuju istana, pasukan Jara Wera (kuda Wera), pasukan Jara Sara'u (Kuda Saru'u), laskar Suba Na'e, Penari Sere, Pengusung Uma Lige dan para tokoh adat Mbojo ikut menyertainya.

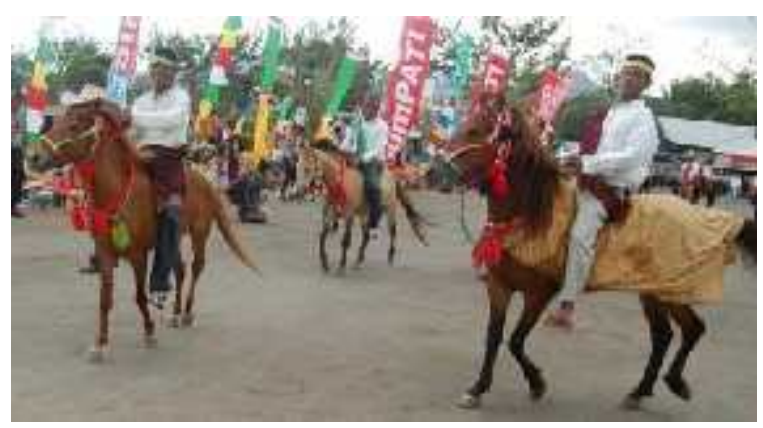

Gambar 2. Pasukan jara wera

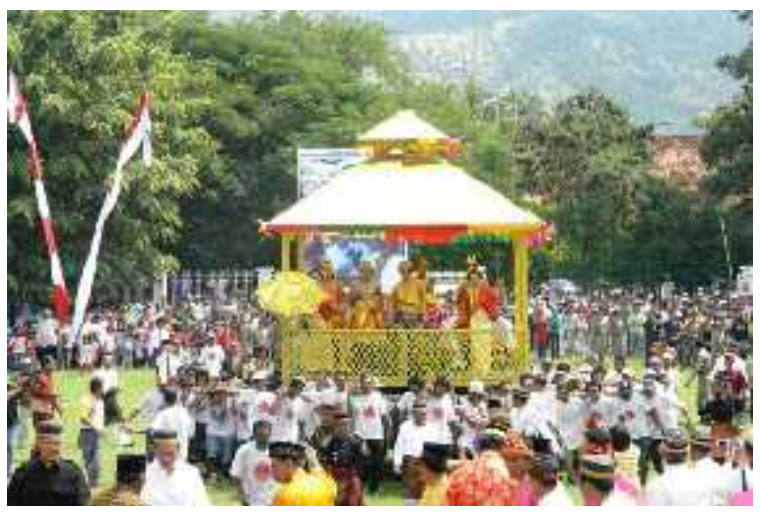

Gambar 3: Rombongan Hanta ua pua.

Setelah rombongan ini sampai di istana, maka akan di sambut oleh sultan dengan disertai atraksi serta seni tari tradisional. Lalu di ikuti oleh pernyataan sultan dalam kesiapannya menerima dan memulai pelaksanaan upacara dengan penyerahan Ua Pua. Kemudian, setelah penyerahan dilakukan penghulu melayu di persilahkan untuk duduk berdampingan dengan sultan sebagai simbol keharmonisan dan kesamaan tujuan. Di bagian akhir pelaksanaan upacara, diadakan dengan membagikan kepada seluruh masyarakat Bima yang hadir, yaitu bunga telur yang berjumlah 99 yang berarti simbol dari nama-nama Allah.

Budaya Hanta Ua Pua ini merupakan budaya yang sedikit diambil dari budaya Melayu namun mengalami perpaduan dan pembaruan dengan budaya asli Bima. Adapun upacara adat Hanta Ua Pua, idul fitri dan idul adha merupakan hari 
besar yang diperingati dengan resmi oleh pemerintahan kerajaan.

\section{Nilai-nilai dalam Upacara Adat Hanta Ua Pua}

\section{a. Nilai Sosial}

Tradisi upacara adat Hanta Ua Pua salah satu budaya yang dimiliki oleh tanah Bima yang pelaksanaan acaranya merupakan salah satu media silaturahmi antar suku di daerah Bima maupun daerah lain di Indonesia. Di samping itu juga, tradisi Upacara Adat Hanta Ua Pua ini juga disisi lain menghidupkan kembali budaya Bima mbolo ro dampa (musyawarah mufakat) dan budaya karawi kaboju (gotong royong) yang keberadaannya juga mulai memudar. Dalam budaya mbolo ro dampa atau yang bisa disebut juga dengan musyawarah dan mufakat. Orang Bima bisa berkumpul tanpa adanya perbedaan dan pembedaan golongan, status sosial dan kelompok baik dari pejabat kesultanan sampai rakyat biasa. Sementara dalam budaya karawi kaboju atau yang bisa disebut dengan gotong royong. Seluruh lapisan masyarakat Bima baik dari pihak kesultanan sampai rakyat biasa berbagi tugas dalam mempersiapkan prosesi upacara. Wujud nyata dari bentuk gotong royong dalam upacara ini ada pada 44 orang yang mengusung Uma Lige (rumah Linge) ditunjuk dari kampung yang berbeda di daerah Bima.

\section{b. Nilai Spiritual}

Tradisi upacara adat Hanta Ua Pua ini merupakan upacara yang tujuan dasarnya adalah menyebarkan ajaran agama Islam yang dilaksanakan dan dilakukan dengan cara dan disesuaikan dengan adat istiadat di daerah Bima. Upacara ini tentu saja banyak mengandung nilainilai agama Islam, nilai Budaya serta nilai sosial yang menjadi pedoman dan acuan hidup masyarakat Bima. Tradisi upacara adat ini juga merupakan salah satu acara penghormatan terhadap baginda besar Nabi Muhammad SAW serta penghormatan terhadap para ulama yang sudah berjuang membawa dan menyebarkan ajaran agama Islam di tanah Bima. Masyarakat Bima sendiri memiliki kepercayaan bahwa dengan melakukan dan melaksanakan acara ini mampu menumbuh dan menambah rasa cinta mereka terhadap ajaran Islam dan baginda Rasul serta dapat menjadi hawo ro ninu (orang yang dimuliakan) dalam mendakwahkan Islam.

\section{c. Nilai Pendidikan}

Tradisi upacara adat Hanta Ua Pua ini juga mengandung nilai pendidikan yang menjadi salah satu hal penting bagi masyarakat di daerah Bima di antaranya, pertama: pendidikan dalam membentuk karakter dan akhlak seseorang. Dalam pembentukan karakter dan akhlak ini, tentu saja baginda rasul Muhammad SAW menjadi panutan dan contoh teladan yang paling baik bagi seseorang. Kedua: menanamkan nilai kesadaran diri kepada masyarakat terhadap pentingnya nilai budaya dan nilai sejarah, terutama sejarah masuk dan berkembangnya ajaran Islam di daerah Bima. Ketiga: menumbuhkan nilai tanggung jawab dan gotong royong terhadap tugas yang diberikan dan dipercayakan kepadanya untuk dijalankan dengan baik.

Adapun pesan moral yang ingin disampaikan melalui tradisi upacara adat Hanta Ua Pua ini di antaranya adalah: pertama, masyarakat dan juga para raja harus menghormati para ulama mengingat para ulama merupakan transmisi ilmuilmu agama. Sehingga patutlah diajarkan secara masal kepada masyarakat tentang adab dan perilaku terhadap para ulama. Kedua, adanya nilai kebersamaan, nilai gotong royong, musyawarah mufakat dan disamping itu juga terdapat point penting bahwa dalam membangun suatu kehidupan kemasyarakatan yang baik dibutuhkan kerukunan dan keharmonisan.

Dalam kehidupan masyarakat Bima, ulama merupakan sumber ilmu syariat sedangkan raja atau sultan merupakan simbol hukum, maka para ulama mencari cara terbaik untuk menebarkan ilmu syariat tersebut dengan legalitas hukum yang jelas sehingga masyarakat luas dengan mudah tunduk dan patuh terhadap syair tersebut. Maka, melunakkan hati raja serta mengingatkannya pada sumpah para leluhur sebelumnya terhadap ajaran Islam suatu keharusan maka dengan demikian dibuatkanlah tradisi upacara adat hanta ua pua sebagai momentum serta sarana untuk pengingat bagi seluruh lapisan masyarakat.

\section{Upacara Adat Hanta Ua Pua sebagai Budaya Islam di Bima}

Kehidupan masyarakat di daerah Bima memang sudah sangat dekat dan kental dengan ajaran dan nilai-nilai agama Islam. Pengaruh budaya Hindu-Budha dan kepercayaan asli suku Bima pun mengalami pergeseran nilai dengan disisipkannya nilai-nilai Islam ke dalamnya. Masyarakat suku Bima asli pada mulanya percaya pada makakamba makakimbi.

Namun, hal tersebut tidak menyebabkan pertengkaran dan permusuhan terhadap kedata- 
ngan ajaran Islam. Kedatangan Islam sendiri di tanah Bima dilakukan dengan cara damai (Azra: 1999). Walaupun mengislamkan kawasan nusantara dilakukan pada waktu dan cara yang tidak seragam karena dipengaruhi oleh tingkat penerimaan ajaran Islam tersebut tergantung dari waktu pengenalannya, watak dan juga budaya lokal yang kental. ajaran Islam lebih mudah masuk pada daerah yang yang memiliki budaya maritim dan terbuka daripada pada wilayah budaya agraris yang lebih tertutup (Azra: 2002).

Melalui tradisi upacara adat Hanta Ua Pua inilah dakwah dan penyebaran agama Islam mulai pada pengisian makna dan nilai-nilai islami yang integratif ke dalam semua jenis musik, seni dan budaya yang akan dikembangkan pada kehidupan langsung masyarakat di daerah Bima. Pada pelaksanaan tradisi upacara adat ini ajaran Islam diperkenalkan tanpa harus keluar dari adat istiadat yang ada yang telah lama mereka pegang teguh, sehingga ketika mereka menerima ajaran Islam, mereka menerimanya dengan suka rela.

Tradisi Hanta Ua Pua ini merupakan suatu kegiatan bersejarah dalam pertumbuhan dan perkembangan ajaran Islam dan juga umat Islam sendiri di daerah Bima. Di dalam pelaksanaannya, tradisi upacara adat ini terdapat beberapa kegiatan yaitu penobatan, peringatan masuk dan berkembangnya ajaran islam di tanah Bima serta bersamaan dengan peringatan maulid nabi besar Muhammad SAW.

Selain itu juga, tradisi upacara adat Hanta Ua Pua ini telah memiliki tempat yang istimewa dalam kehidupan masyarakat muslim di daerah Bima karena diadakan dengan tujuan dan makna mengangungkan nilai-nilai dan ajaran Islam. Tradisi upacara ini juga merupakan bukti perkembangan ajaran Islam di tanah Bima. Tradisi upacara ini juga berperan sebagai penghormatan kepada ajaran Islam dan ulama serta dapat menjadi media dakwah ajaran Islam di Indonesia secara luas dan di daerah Bima secara khusus.

Ada beberapa fungsi dari tradisi upacara adat Hanta Ua Pua sebagai salah satu budaya religi di tanah Bima diantaranya adalah :

\section{a. Sebagai pengingat}

Sejak berdirinya kesultanan Bima yang dibantu oleh para ulama, sultan berkewajiban menjalankan ajaran agama secara kaffah (menyeluruh). Adanya tradisi upacara adat ini tentu saja untuk menjadi pengingat dan untuk menegaskan kembali bagi pemimpin baru dan masyarakat akan tugas dan kewajiban mereka dalam melanjutkan syiar islam.

\section{b. Sebagai penghormatan kepada ulama}

Tradisi upacara ini diresmikan sebagai salah satu upacara terbesar ajaran Islam setelah idul fitri dan idul adha yang rutin diadakan setiap tahunnya. Tradisi upacara adat ini juga merupakan penghormatan kepada ulama yang telah bersusah payah menyebarkan syiar Islam.

Ulama dalam pandangan masyarakat Bima digambarkan sebagai hawo ra nino yaitu tempat berteduh dan berkaca yang dijadikan panutan oleh masyarakat yang hampir setara dengan raja. Kemuliaan ini dipandang penting oleh masyarakat bima karena memandang para ulama adalah jalur transmisi ilmu-ilmu syariat.

\section{c. Sebagai momentum silahturahmi dan bermusyawarah mufakat}

Tradisi ini disamping sebagai wujud memperingati hari maulud nabi besar Muhammad SAW dan mengenang jasa para ulama dalam usaha menyebarkan ajaran islam di daerah Bima, juga menjadi kegiatan dan sarana untuk mewujudkan dan menunjukan rasa kebersamaan dan persatuan dalam masyarakat.

Dalam pelaksanaannya seluruh suku di tanah Bima akan berkumpul dan berbaur menjadi satu sehingga terjalin interaksi dan komunikasi yang baik. Di samping itu, dalam mempersiapkan upacara adat ini, masyarakat Bima secara gotong royong saling bekerja sama dan tolong menolong sehingga terbangun dan terjalin hubungan yang rukun antar masyarakat.

\section{d. Sebagai perantara dan wadah dalam dakwah ajaran Islam.}

Seperti yang disebutkan dalam penelitian yang dilakukan sebelumnya, budaya Hanta Ua Pua menjadi salah satu media penyebaran ajaran Islam di daerah Bima pada masa awal masuknya ajaran Islam. Tradisi upacara adat ini memiliki hubungan erat dengan dakwah ajaran islam karena berkaitan langsung dengan sejarah masuk dan berkembangnya islam itu sendiri. Dakwah juga memiliki simbiosis yang erat dengan tradisi upacara adat Hanta Ua Pua ini karena sejalan dengan nilai-nilai kemanusiaan, kebangsaan dan kewargaan bersamaan dengan nilai-nilai islami yang bertujuan memuliakan, menyelamatkan dan membahagiakan masyarakat. 


\section{KESIMPULAN}

T radisi upacara Hanta Ua Pua ini merupakan salah satu kearifan lokal dari budaya Bima yang merupakan salah satu simbol dan jejak ajaran Islam. Tradisi upacara ini adalah budaya yang tergabung dari budaya Melayu dengan adat istiadat masyarakat asli Bima. Tradisi ini Pertama kali diperkenalkan pada masa pemerintahan kesultanan Abdul Khair Sirajuddin pada tanggal 12 Rabiul Awal.

Tradisi upacara adat Hanta Ua Pua ini merupakan bukti nyata adanya jejak-jejak kerajaan Islam di tanah Bima. Tradisi upacara adat ini merupakan budaya yang dicangkok dari budaya melayu kemudian diangkat dan diperkenalkan kepada masyarakat asli Bima dan disesuaikan dengan adat dan istiadat yang sudah ada sehingga dapat diterima dengan baik dan suka rela.

Selain sebagai media dakwah, tradisi upacara ini juga merupakan salah satu simbol dan bukti penghormatan kepada ilmu agama dan ulama yang berjuang menyebarkannya. Dengan tetap dilaksanakannya serta dilakukannya tradisi upacara adat ini diharapkan dapat membentuk karakter masyarakat Bima yang berpedoman teguh pada nilai-nilai agama tanpa melupakan budaya dan adat istiadat yang ada.

Tradisi upacara adat Hanta Ua Pua ini merupakan bentuk dari seni tradisional yang diciptakan dalam rangka mensyukuri nikmat Allah SWT. Selain itu tradisi upacara adat ini juga sebagai bukti penghayatan terhadap kebesaran Allah baik yang terdapat di alam maupun dari hasil buatan tangan manusia sendiri.

\section{E. UCAPAN TERIMA KASIH}

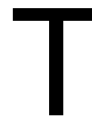
erimakasih penulis sampaikan kepada bapak Mukhamad Murdiono yang dengan sabar telah memberikan bimbingan, masukan dan arahan kepada penulis. Selain itu juga kepada Program Pascasarjana Universitas Negeri Yogyakarta yang telah mendukung artikel ini sepenuhnya dan pengalaman belajar yang menyenangkan dan penuh motivasi sehingga penulis terinspirasi untuk menulis artikel ini.

\section{DAFTAR PUSTAKA}

Alan Malingi. (2016). 'Syiar Islam dalam Upacara Adat Hanta Ua Pua di Tanah Bima Nusa Tenggara Barat'. Jurnal Lektur Keagamaan, Vol. 14, No. 1, 2016: 29-54.

Arikunto. (2010). Prosedur Penelitian. Suatu Pendekatan Prakti. Jakarta: Rineka Cipta

Asbah, (2017). 'Upacara Ua Pua sebagai media dakwah dan syiar Islam pada penyebaran agama Islam di Bima'. Historis. Vol. 2, No. 1, Juni 2017, Hal. 11-18

Azra, A. (1999). Renaisens Islam Asia Tenggara, Sejarah Wacana dan Kekuasaan. Bandung: PT. Remaja Rosda Karya. Hal: 8.

Azra, A. (2002). Islam Nusantara: Jaringan Global dan Lokal. Bandung: Mizan. Hal: 18.

Fitriana, A. (2019). 'Budaya Rimpu sebagai eksistensi perempuan Islam di tanah Bima'. Jurnal Antropologi: Isu-Isu Sosial Budaya. Vol.21, no. 02.

Ismail, M. Hilir. (2008). Kebangkitan Islam di Dana Mbojo 1540-1950. Bogor: CV. Binasti. Hal: 11.

Ismail, M. Hilir. (2004). Peranan Kesultanan Bima dalam Perjalanan Sejarah Nusantara. Mataram: Gunung Agung I. Hal: 17.

Jumiati, (2017). Hanta Ua Pua: Sejarah tradisi keagamaan di Bima abad xvii-xxi.

Mardotillah, M. (2016). 'Silat: Identitas budaya, pendidikan, seni bela diri, dan pemeliharaan kesehatan'. Jurnal Antropologi: Isu-Isu Sosial dan Budaya. Vol. 18. no. 2.

Muhammad, R. (2010). Upacara Adat Hanta Ua Pua. Mataram: PT. Mahani Persada. Hal: 22-23.

Panggabean, H. (2015). Kearifan Lokal Keunggulan Global. Elex Media Komputindo.

Rapanna, P. (2016). Membumikan Kearifan Lokal Menuju Kemandirian Ekonomi. Sah Media.

Ranjabar, R. (2006). Sistem Sosial Budaya Indonesia. Bogor: Ghalia Indonesia. Hal: 115.

Retno Kartini Savitaningrum Imansah (2017). 'Masjid Sultan Muhammad Salahuddin Bima; Arsitektur, Misi Agama dan Kekuasaan'. Jurnal Lektur Keagamaan, Vol. 15, No. 2, 2017: 390-419.

Salmin \& Jasman, (2017). 'Implementasi nilai-nilai lokal dalam pengembangan pariwisata budaya di kabupaten Bima'. Jurnal Administrasi Negara. Volume 14 Nomor 3 Juli-Desember 2017 | 94103

Saputra, D. S. \& Nurbaiti. (2010). Kearifan Lokal yang Terkandung Dalam Upacara Tradisional Kepercayaan Masyarakat Sakai-Riau. Direktorat Jenderal Kebudayaan.

Tajib, A. (1995). Sejarah Bima Dana Mbojo. Jakarta: PT. Harapan Masa PGRI. Hal: 140. 
Tawalinuddin Haris. (2012). 'Masuknya Islam dan Munculnya Bima sebagai Pusat Kekuasaan Islam di Kawasan Nusa Tenggara'. Jurnal Lektur Keagamaan, Vol. 10, No. 1, pp. 23 - 50

Zuriatin, N. (2018). 'Kebudayaan Islam yang Berkembang di Kesultanan Bima pada Abad Ke XVII M'. Jurnal Pendidikan IPS, Vol. 8. No. 2. 